\title{
Application of Chosen Fraudulent Detection Technique in the Slovak Business Environment
}

\author{
Katarina Kramarova ${ }^{1, *}$, Katarina Valaskova $^{2}$ \\ ${ }^{1}$ University of Zilina, Faculty of Operation and Economics of Transport and Communications, \\ Department of Economics, Univerzitná 8125/1, 01003 Žilina, Slovakia \\ ${ }^{2}$ University of Zilina, Faculty of Operation and Economics of Transport and Communications, \\ Department of Economics, Univerzitná 8125/1, 01003 Žilina, Slovakia
}

\begin{abstract}
The paper analyses the possibility of applying chosen fraudulent detection technique in the condition of Slovakia and then evaluates its explanatory power. The authors based on the idea that in addition to positive effects of globalization, negative effects on the activity of economic entities are also manifestations of this process. As the society has become more dependent on information technologies, increased globalisation and greater interconnectedness, certain exposure to negatives has expanded right along with them. One of this negative effect is clearly a financial crime of various type, including fraudulent financial reporting. The financial statements should "describe" factually and truthfully the financial and economic health of a company because it is the main sources of information for various type of stakeholders. Handling of it (considering in the context of financial crime) is primary the responsibility of owners or managers (provided the separation of the ownership structure from the management structure). Reasons for doing so are different. Their common denominator is the artificial creation of information asymmetry to obtain different "benefits". It is therefore logical that the need for constructing techniques that would reveal an unacceptable legal action by a company in a financial reporting process is at the forefront.
\end{abstract}

\section{Introduction}

Fraudulent financial reporting has increased in frequency in last two decades and usually occurs in the form of deliberate falsification of the financial statements in order to obtain some form of benefits. Current time is characterized by the fact that decision-making process of any entity is highly dependent on the quality of information obtained. The aim of the existence of the financial statements is enshrined directly in the legislative of all developed economies, including Slovakia. Based on the Act No. 431/2002 Coll. on Accounting as amended and on amendments of some act (Section 17 (1)), the financial statements is "structure presentations of facts representing the subject of accounting, made available to persons who use such information (in this Act referred to as "users")". [1] "The diversity of interests and objectives of individual groups of users and creators of financial statements presents the risk of manipulation of financial statements in the context

\footnotetext{
* Corresponding author: katarina.kramarova@fpedas.uniza.sk
} 
of true and fair view as defined in the national accounting legislation." [2] Financial statements are the most important sources of information about the financial and economic status of a company. $[3,4,5]$

If we assume that that the financial statements should provide factual and truthful information about the financial and economic vitality of a company, a targeted misleading produces or deepens already existing information asymmetry between the providers of financial information and the group of its users. Financial statements are the basic

Kováčová - Rowland consider a deliberate falsification of the financial statements to be the highest form of fraudulent financial reporting. Except this, they distinguish its two other "lighter forms" - creative accounting that moves within the existing legislative framework or exploits its weaknesses and unintentional errors in accounting mirroring also in the financial statements. [6] In some situation, intersections of incorrect reporting (in general meaning) are subject the proof whether or not it is intentional fraud. E.g. [6 - 10] link fraudulent financial reporting with a financial statement that contains falsification of figures, which do not represent the true scenario. Wells considers fraudulent financial reporting, asset misappropriation and corruption the highest level of fraud tree. $[11,12]$ Reasons behind fraudulent financial reporting are different, e.g. bias wrecker of tax duties (management/owner), increasing the value of a company (management/owner), gaining more favourable conditions of debt financing (management/owner), gaining grants (manager/owners), deceiving business partners (e.g. suppliers/buyers, insurance companies), existing and potential investors (management/owner), rewards based on financial results of a company (management/employees), conceal losses and stolen property (managements/employees).

The establishing a basic framework of the economic and financial control logically falls within the competence of a company itself - its top management or owner(s) (provided absence of separation of the ownership structure and corporate governance). It should include both control ex-ante (control before the accounting case is recorded) and ex-post (control of already recorded accounting case) and internal audit (continuously). It is obvious that the existence of internal audit itself, not mentioning its more sophisticated forms, is typical for large companies, as the process of internal audit requires financial, personnel and technological sources. The external level of control is whether optional or obligatory; the obligatory control includes auditing of the financial statements following the existing legislative and control performed at the initiative of the public authority (e.g. Financial Administration in the case of Slovakia).

Generally, fraud by management/owners is more difficult to detect than fraud by employees mainly because management/owners have such power and competence to hiding own fraudulent behaviour. [13] Authors of [14] discern two main detecting strategies for fraudulent financial reporting - auditing and statistics. Kouřilová presents a more detailed classification. She states that the financial statements' performance is possible to enhance inter alia by identifying procedures and methods that aim to detect accounting inconsistencies (intentional, unintentional) through: legislative ethics and principles of responsibility, software solutions, strategic fraud detection models, applying the knowledge of the theory of behavioural accounting and behavioural finance, and mathematicalstatistical detection models. $[15,16]$

\section{Methodology}

The objective of the paper is to analyse the possibility of using the chosen detection techniques of earnings manipulation on the example of the selected company, which undertakes business in the Slovak business environment and then evaluate the techniques' explanatory power. The test subject is an enterprise that "optimized" its financial statements 
for tax purposes and which was officially convicted from the financial fraud in 2013 and 2014. The tax fraud was categorized as an administrative offense and the company (as a taxpayer) was obliged additionally to pay a tax and penalty.

The analysed period covers the years $2011-2015$. We have taken into account the data from the financial statements (balance sheet and income statement), which were presented to the state authority as "ordinary financial statements". The company has a legal form of a limited liability company, which obliges it to keep a double entry accounting in accordance with the Slovak accounting standards and legislation. In terms of the size classification of an accounting unit, it is characterized as a small enterprise and thereby is not obliged to audit the financial statements. The SK NACE code of the company is 68.20.0.

The tax fraud is a criminal offense involving several variants of different content. In contrast to aggressive tax optimization, imprisonment is also a possible kind of a sanction in the case of the tax fraud. In this content, the greatest challenge for the administrative authorities and criminal justice is to determine a strict dividing line between the tax fraud and aggressive tax optimization.

\subsection{Fraudulent detection techniques using financial ratios}

We have picked up two detection techniques that rely on chosen financial ratios - the Beneish model and Kanapickiene - Grundiene model (hereinafter "KG model"). Both models suppose that financial ratios are able to spot discrepancies within an enterprise's financial statements, however they authors choose different financial ratios for fraud investigation. While the Beneish model tries to determine the likelihood of financial statements manipulation rather using the financial ratios as on-year indexes, the KG model uses financial ratios that are quantified using the data from the same year. Their common denominator is that neither of the models was developed in the conditions of the Slovak business environment and is not fully in accordance with the Slovak accounting standards and other regulations covering financial reporting in our country. The Beneish model is based on the GAAP, the KG model on the Lithuanian accounting and reporting standards and thereby we have approximated some input financial data in accordance with the content definition of the financial indicators in the source research papers. Logically in our conditions, the approximation affects the ability of the models to distinguish and therefore we do not have only examined the final score but also the development of individual financial indicators.

\subsubsection{Beneish model}

The Beneish model (Beneish M-score; USA) is a mathematical probabilistic model based on probit regression method and indicates the perspectives concerning the tendency of a company for fraudulent financial reporting. It belongs among the first fraudulent detection techniques in financial reporting. It is generally known and many researchers have been trying to apply it in conditions of other than U.S. economy. Fraudulent financial reporting is an activity of earnings manipulation where management violates the GAAP in order to beneficially present a company's financial performance. [17] The model was conceived on the sample of the companies (74 in the period 1982 - 1992) that were actual accused of fraudulent financial reporting. It consists of 8 financial indicators (see Table 1) that are calculated from the financial statements (starting in the year when a company was suspicious from reporting violating). The results of the analysis show that companies, which committed financial statement fraud had low asset quality and gross margin ratio and were highly leveraged. [17 - 21]

The M-score has a character of probability - higher M-score indicates higher likelihood of manipulation. The test of the model showed that it correctly identified from $58 \%$ to $76 \%$ 
of manipulators and incorrectly $7.6 \%$ to $17.5 \%$ of non-manipulators. The procedure of the analysis requires considering at least 2 years of financial reporting to be able to detect the company's unusual behaviour. [17] However, to identify the trend of a company's financial statement reporting, it is suggested to analyse the data at least for 5 years. [14] The threshold of the M-score is -2.22 and the author concluded that if the company scored greater than -2.22 (a less negative or positive number) there was a probability that a company manipulated with the profit and financial statements. [15] The M-score is calculated as follows; the abbreviations of the financial indicators are explained in the Table 1.

$$
\begin{gathered}
M=-4.84+0.92 \times D S R I+0.528 \times G M I+0.404 \times A Q I+0.892 \times S G I+0.115 \times D E P I+ \\
0.172 \times S G A I+0.327 \times L V G I+4.697 \times T A T A
\end{gathered}
$$

\subsubsection{Kanapickiene - Grundiene model}

The KG is a model that detects fraudulent financial reporting based on a logistic regression. Similar to the Beneish model it is based on the assumption that financial ratios carry the information that can be used to identify fraudulent reporting in case of the analysed company. The authors initially analysed existing academic literature based on which subsequently identified 51 financial ratios as potential discriminant indicators. Their discriminant ability was analysed on the sample of 40 fraudulent and 125 non-fraudulent Lithuanian companies during the period 1998 - 2009. 32 financial ratios proved to be efficient, which in general cover the areas of the profitability of sales, profitability of investment, liquidity, solvency, activity and structural ratios of assets and equity. The final logistic regression model includes 4 of them (see Table 1.) and its overall classification ability is $85 \%$ of correctly classified companies. When the P-value is higher than $50 \%$, financial statements are fraudulent; when the P-value is lower than $50 \%$, are nonfraudulent. [22] The P-value and the KG model is calculated as follows; the abbreviations of the financial indicators are explained in the Table 1.

$$
\begin{gathered}
P=1 /\left(1+e^{K G}\right) \\
K G=5.768+4.263 \times A S R+0.029 \times A R+4.766 \times S R+1.936 \times L R
\end{gathered}
$$

\section{Results}

In the analysed years, the value of the company's assets dropped by $24 \%$ (from $€ 4.698$ million to $€ 3.524$ million) as the result of the negative values of EAT in all reporting years, except 2015 . The value of the equity developed similarly and declined by up to $68 \%$ (from $€ 2.793$ million to $€ 0.906$ million). In all years the company reported negative EAT and EBT, the only exception is the year 2015 when the company was in plus numbers (EAT $€$ 160,636 ; EBT $€ 178,653$ ). The lowest value of EAT (loss) the company recorded in $2014 €$ -1.200 million. The cumulative value of the loss was $€ 1.857$ million in 2015 (not included EAT 2015) and the average value of EAT is approx. $€-366,100$. Accumulation of losses over the years increased also the debt ratio of the company (from $41 \%$ in 2010 up to $80 \%$ in 2014). The company' sales fluctuated - the highest sales were reported in 2012 (€1.638 million), the lowest in 2010 ( $€ 557,932$ ), the average value of sales for the analysed periods is approx. $€ 965,600$. Despite the relatively high values of the company's assets, its cash position we may define as weak. The average value of financial assets (cash, bank accounts, short-term deposits, and short-term securities) is only approx. $€ 82,089$ (less than $2 \%$ of the average value of the assets). 
Table 1. shows the individual financial indicators of both models, their formulas and values, and resulting score of the models (M-score, P- value) for each year.

Table 1. Results - Beneish model, KG model

\begin{tabular}{|c|c|c|c|c|c|c|}
\hline BENEISH MODEL (M): Indicator (abbrv.), Formula & $\begin{array}{l}\text { Weight of } \\
\text { Indicator }\end{array}$ & $2011 / 2010$ & $2012 / 2011$ & $2013 / 2012$ & $2013 / 2014$ & 2014/2015 \\
\hline 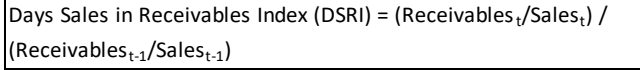 & 0.920 & 0.8047 & 1.0273 & 0.8481 & 0.7015 & 2.0199 \\
\hline 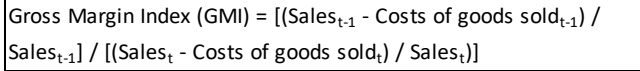 & 0.528 & 1.0515 & 0.8859 & 0.9729 & 1.0782 & 0.9700 \\
\hline 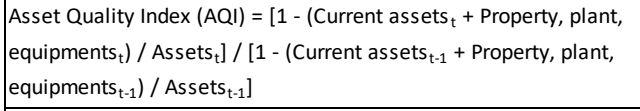 & 0.404 & 0.9982 & 1.0232 & 0.0218 & 0.9119 & 4.9239 \\
\hline Sales Growth Index (SGI) $=$ Sales $_{t} /$ Sales $_{t-1}$ & 0.892 & 0.6852 & 1.8887 & 1.6117 & 0.6620 & 0.6686 \\
\hline $\begin{array}{l}\text { Depreciation Index }(\mathrm{DEPI})=\left[\text { Depreciation }_{\mathrm{t}-1} /\left(\text { Depreciation }_{\mathrm{t}-1}+\right.\right. \\
\left.\left.\text { net Property, plant, equipments } \mathrm{t}_{\mathrm{t}-1}\right)\right] /\left[\text { Depreciation }_{\mathrm{t}} /\right. \\
\left.\left(\text { Depreciation }_{\mathrm{t}}+\text { net Property, plant, equipments } \mathrm{s}_{\mathrm{t}}\right)\right]\end{array}$ & 0.115 & 1.3785 & 0.9816 & 0.9315 & 0.9277 & 1.6853 \\
\hline $\begin{array}{l}\text { Sales General and Administrative Expenses Index (SGAI) = (Selling, } \\
\text { general, administrative expense } \mathrm{t}_{\mathrm{t}} / \text { Sales }_{\mathrm{t}} \text { ) / (Salling, general, } \\
\text { administrative expense }_{\mathrm{t}-1} / \text { Sales }_{\mathrm{t}-1} \text { ) }\end{array}$ & 0.172 & 0.0000 & 1.9025 & 1.4566 & 1.5291 & 0.2943 \\
\hline $\begin{array}{l}\text { Leverage Index (LVGI) }=[(\text { Long term debt } \\
\text { t } \\
\left.\text { Assets }_{\mathrm{t}}\right] /\left[\left(\text { Current }_{\text {liabilities }}\right) /\right. \\
\text { (Long term debt } \\
\mathrm{t}-1\end{array}$ & 0.327 & 1.0818 & 1.0382 & 1.2902 & 1.4913 & 0.9342 \\
\hline 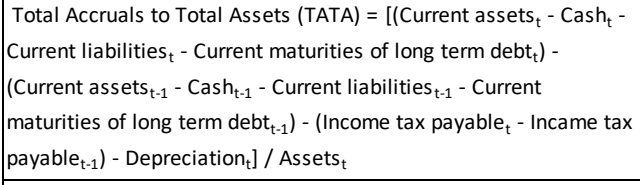 & 4.697 & -0.0681 & -0.0624 & -0.0913 & -0.0607 & -0.0485 \\
\hline Intercept -4.840 & M-score & -2.3378 & -0.8424 & \begin{tabular}{|l|}
-1.7849 \\
\end{tabular} & -2.0943 & 0.4384 \\
\hline KG MODEL (KG): Indicator (abbrv.), Formula & $\begin{array}{l}\text { Weight of } \\
\text { Indicator }\end{array}$ & 2011 & 2012 & 2013 & 2014 & 2015 \\
\hline Assets Structure Ratio (ASR) = Inventories / Assets & 4.263 & 0.0023 & 0.0043 & 0.0027 & 0.0070 & 0.0020 \\
\hline Activity Ratio $(A R)=$ Sales / Fixed Assets & 0.029 & 0.1193 & 0.2575 & 0.4502 & 0.3107 & 0.2166 \\
\hline Solvency Ratio (SR) = Liabilities / Assets & 4.766 & 0.3982 & 0.4134 & 0.5333 & 0.7954 & 0.7430 \\
\hline Liquidity Ratio (LR) = Cash / Current liabilities & 1.936 & 0.6165 & 0.4987 & 1.5600 & 0.5748 & 0.3655 \\
\hline Intercept 5.768 & $P(\%)$ & 6.516 & 5.698 & 45.477 & 30.458 & 18.179 \\
\hline
\end{tabular}

Source: own collaboration

The results indicate the analysed company is a likely manipulator, however only based on the Beneish model. Moreover the model also flags the years, when the company it was actually proven fraudulent financial reporting - 2013, 2014 (this indicates the values of the M-score in periods 2013/2012, 2014/2013 and 2015/2014). As you can see, the values of the individual financial indicators are relatively unstable. The highest volatility (expressed as standard deviation) we identified in the case of the AQI (1.5706; enamours changes in the periods 2013/2012 and 2014/2015), which is a ratio that measures changes in the structure of assets taking into account other than current assets and non-current assets, in this case namely plant, property and equipment. The indicative value of this ratio is 1 , which indicates that an enterprise did not any significant changes in its asset structure, in other case the result suggests an excessive capitalization of costs. The extensive change of the ratio in 2013/2012 was caused by dropping the value of intangible assets (in the process of acquiring) from approx. $€ 266$ thousand to almost zero. In 2014/2015 the change of the index was mainly caused by increasing the value of accruals on the side of assets of the balance sheet (from approx. $€ 4.5$ thousand to $€ 21.3$ thousand). On the other hand, the lowest level of fluctuation we identified in the case of the TATA $(0.0031)$, which we consider positive. 
Regarding the results of the KG-model, the model did not demonstrate that the company would be a manipulator at all; however, in 2013 the P-value approached close to the marginal value $50 \%$. As it can be seen, it happened mainly because of the high value of liquidity ratio. This year, the company reported the highest balance of financial assets (as we have already mentioned in the text above) and disproportionately higher compared to other years ( $€ 40,059$ in $2010, € 37,405$ in $2011, € 49,622$ in $2012, € 27,631$ in 2014 , and $€$ 22,879 in 2015). In terms of the development of this ratio over time, we can claim that the ratio fluctuated the most from the group of all financial indicators of the $\mathrm{KG}$ model.

\section{Conclusion}

The objective of the paper was to analyse the possibility of using the chosen detection techniques of earnings manipulation and fraudulent financial reporting on the example of the selected company in conditions of Slovakia and then evaluate the techniques' explanatory power. The test subject was an enterprise that "optimized" its financial statements for the tax purposes and which it was officially proved that made the financial fraud. The analysed period covered the years $2010-2015$.

The findings show that only one of the techniques used identified the company as fraudulent - the Beneish model. The KG model did not flag it as a definite manipulator; however, in 2013 the P-value almost reached the threshold 50\%. The Beneish model correctly identified the company as a manipulator also in the years when it was officially proved the fraudulent financial reporting $(2013,2014)$.

Although the discriminatory ability of the model has been established in this case, it cannot be regarded as a general means of unambiguously designating any company as a manipulator. The results should not be taken as the end of a possible fraud investigation, but as the beginning. For the practical use, other tools should also check if the classified company is a potential manipulator, because the Beneish model has a significant portion of "false positives". [23]

Other important fact (for both models applied) is that they were not developed in the economic and legislative environment that would be typical for Slovakia. From this point of view, the basic obstacle is that the financial statements, which is a mirror of financial and economic transactions of a company (expressed in monetary values) is in Slovakia prepared in accordance with accounting standards that differ from the standards accepted by the US GAAP and Lithuanian accounting standards. This fact has taken an important role mainly in the case of the Beneish model, since we had to approximate some input data to quantify individual indicators and the $\mathrm{M}$-score. It would be appropriate to define the general approach toward to identification of indicators that are not directly reported in the Slovak financial statements. Thereby it is needed to do deeper and comprehensive research on any fraudulent detection technique and its application in conditions of Slovakia.

This paper was supported by the Slovak Research and Development Agency under Grant number APVV-17-0546: Variant Comprehensive Model of Earnings Management in Conditions of the Slovak Republic as an Essential Instrument of Market Uncertainty Reduction.

\section{References}

1. Zákon č. 431/2002 Z. z. o účtovnítve v znení neskorších predpisov. Available at: https://www.slov-lex.sk/pravne-predpisy/SK/ZZ/2002/431/20170101

2. Z. Drábková, Analysis of possibilities of detecting the manipulation of financial statements in terms of the IFRS and Czech accounting standards. Acta Universitatis 
Agriculturae et Silviculturae Mendelianae Brunensis, Mendel University Press, 63(6), 1859-1866 (2015)

3. V. Bartošová, P. Král', A methodological framework of financial analysis results objectification in the Slovak Republic. European Proceedings of Social and Behavioural Sciences, 17, 189-197 (2016)

4. J. Klieštiková, M. Mišánková, T. Klieštik 2017, Bankruptcy in Slovakia: international comparison of the creditor's position. Oeconomia Copernicana, 8(2), 221-237 (2017)

5. A. Siekelová, B. Kollár, I. Weissová, Impact of credit risk management. Procedia Economics and Finance, 26, 325-331 (2015)

6. M. Kováčová, Z. Rowland, Kreatívne účtovníctvo ako latentný nástroj earnings management. Podniková ekonomika a manažment, 3, 36-42 (2018)

7. C. Spathis, Detecting false financial statements using published data: Some evidence from Greece. Managerial Auditing Journal, 17(4), 179-191 (2002)

8. A. F. Dalkilic, Fraudulent financial reporting techniques: analysis of accounting and auditing enforcement releases. International Journal of Contemporary Economics and Administrative Sciences, 7(3-4), 224-242 (2017)

9. R. Sadaf, J. Oláh, J. Popp, D. Máté, An investigation of the influence of the worldwide governance and competitiveness on accounting fraud cases: a cross-country perspective. Sustainability, 10(3), 1-11 (2018)

10. T. Sosnowski, Earnings management in the private equity divestment process on Warsaw Stock Exchnage. Equilibrium - Quarterly Journal of Economics and Economic Policy, 13(4), 689-705 (2018)

11. J. T. Wells, Principles of Fraud Examination (4 ed.). Wiley: Hoboken, 2014, 544 (2014)

12. J. T. Wells, Corporate Fraud Handbook: Prevention and Detection (5 ed.). Blackwell Science Publ.: Oxford, 2017, 415 (2017)

13. P. Krišková, Odhal'ovanie podvodu pri audite účtovnej závierky, Účtovníctvo a audítorstvo $\mathrm{V}$ procese svetovej harmonizácie, p. 55-59. Available at: http://www.kuaa.sk/uploads/Odha\%C4\%BEovanie\%20podvodu\%20pri\%20audite\%20 \% $3 \%$ BA\%C4\%8Dtovnej\%20z\%C3\%A1vierky.pdf, (2011)

14. A. A. Nooraslinda, O. Rohana, S. M. A. Maznah, M. A. M. Affendi, O. Normah, Fraud detection: Benford's law vs Beneish model, 2013 IEEE Symposium on Humanities, Science and Engineering Research, 726-731 (2013)

15. J. Kouřilová, Q-test-DMFCA jako možný rychlý zpúsob kontroly účetnictví a obchodních aktivi v podniku. Český finanční a účetní časopis, 10(1), 55-69, (2015)

16. J. Kouřilová, I. Stejskalová I, Creative accounting from the perspective of management. 2nd International Multidisciplinary Scientific Conference on Social Sciences and Arts (SGEM 2015), Albena, BULGARIA, AUG 26-SEP 01, 2015, 213-222 (2015)

17. M. D. Beneish, The detection of earnings manipulation. Available at: http://citeseerx.ist.psu.edu/viewdoc/download?doi=10.1.1.195.3676\&rep=rep1\&type= pdf (1999)

18. Tarjo, Herawati, N., Application of Beneish M-Score model and data mining to detect financial fraud. Procedia - Social and Behavioural Sciences, 211, 924-930 (2015)

19. T. Ahmed, J. Naima, J., Detection and analysis of probable earnings manipulation by firms in a developing country. Asian Journal of Business and Accounting, 9(1), 59-81 (2016) 
20. Z. Drábková, CFEBT method as a tool of decreasing information asymmetry in accounting and as a part of internal controlling systems. 13th International Conference on Liberec Economic Forum, Liberec, CZECH REPUBLIC, SEP 11-13, 2017, 319-329 (2017)

21. Ö. Ahmet (2018), The use of Beneish model in forensic accounting: evidence from Turkey. Journal of Applied Economics and Business Research, 8(1), 57-67 (2018)

22. R. Kanapickiene, Ž. Grundiene, The model of fraud detection in financial statements by means of financial ratios. Procedia - Social and Behavioral Sciences, 213, 321-327 (2015)

23. V. Petrík, Application of Beneish M-score on selected financial statement. Košická bezpečnostná revue, 2, 307-312 (2016) 